\title{
Correlation of JKR Probe with Undrained Shear Strength
}

\author{
Mohd Fairus Yusof ${ }^{1,2,}$, Md Nor Faliq Abd Khalid ${ }^{2}$, Saiful Azhar Ahmad Tajudin ${ }^{1,2}$, \\ Aziman Madun ${ }^{1,2}$, and Mohd Hazreek Zainal Abidin ${ }^{1,2}$ \\ ${ }^{1}$ Research Center for Soft Soil (RECESS), UTHM, 86400 Parit Raja, Batu Pahat, Johor, Malaysia \\ ${ }^{2}$ Faculty of Civil and Environmental Engineering, UTHM, 86400 Parit Raja, Batu Pahat, Johor, \\ Malaysia
}

\begin{abstract}
The JKR probe test is a popular field test in Malaysia, and is especially used in soft soil areas to determine bearing capacity. However the correlation of undrained shear strength $\left(\mathrm{S}_{\mathrm{u}}\right)$ and the JKR probe test is not available at this moment. This study was performed to develop an empirical correlation of JKR probe and undrained shear strength of soft to stiff soil. In order to produce the correlation, the JKR probe test and the vane shear test have been performed at Universiti Tun Hussein Onn Malaysia (UTHM). Six JKR probe tests and 12 field vane shear tests were performed in close proximity to obtain good correlation. The results show that undrained shear strength and JKR probe can be correlated as $S_{u}=18 J^{0.3}$. The proposed correlations will serve as a reference for engineers in estimating undrained shear strength, especially in low-risk construction design.
\end{abstract}

\section{Introduction}

The JKR probe is a simple site investigation procedure that is relatively inexpensive. The probe is often used in Malaysia, especially for preliminary site investigation, to assess the subsoil layer and the bearing capacity of soils. It can also be used effectively to identify soft or weak layer materials or slip plane failure [1]. The use of the probe test may reduce the number of bore holes required and reduce the overall cost of the project.

JKR probe is slightly different with the Mackintosh probe in terms of cone angle, diameter of rods and couplings, hammer weight and height of hammer free fall, as shown in Table 1. However, for practical application, the results of JKR Probe and Mackintosh Probe may be considered equivalent [1]. The bearing capacity of the soil can be simply obtained by using a correlation graph, as shown in Fig. 1.

\section{Correlations of Mackintosh and JKR Probe}

The correlation of JKR probe test with undrained shear strength has not been addressed in detail in the literature. However, there have been several correlations proposed from

* Corresponding author: fairus@uthm.edu.my 
Mackintosh Probe test $[2,3]$. The detail of correlations of the undrained shear strength, $\mathrm{S}_{\mathrm{u}}$ $\left(\mathrm{kN} / \mathrm{m}^{2}\right)$ and Mackintosh probe $(\mathrm{M})$ is shown in Table 2.

Table 1. Difference between JKR probe and Mackintosh probe

\begin{tabular}{|c|c|c|c|c|c|}
\hline Equipment & $\begin{array}{c}\text { Cone } \\
\text { angle } \\
\left({ }^{\circ}\right)\end{array}$ & $\begin{array}{c}\text { Diameter } \\
\text { of rods } \\
(\mathbf{m m})\end{array}$ & $\begin{array}{c}\text { Diameter of } \\
\text { coupling } \\
(\mathbf{m m})\end{array}$ & $\begin{array}{c}\text { Weight of } \\
\text { hammer } \\
\mathbf{( k g})\end{array}$ & $\begin{array}{c}\text { Height of } \\
\text { hammer } \\
\text { fall (mm) }\end{array}$ \\
\hline JKR Probe & 60 & 12 & 22 & 5.0 & 280 \\
\hline Mackintosh Probe & 30 & 13 & 24 & 4.5 & 300 \\
\hline
\end{tabular}

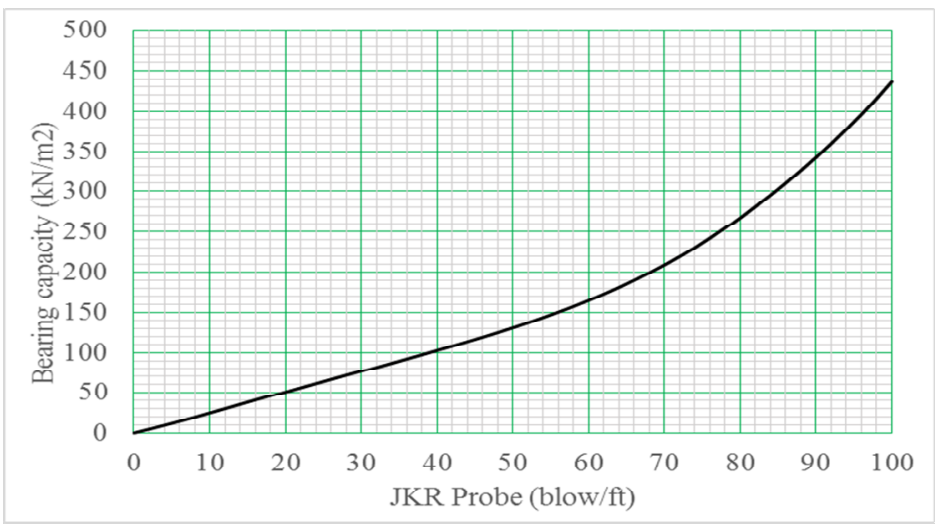

Fig. 1. Estimation chart of bearing capacity

Table 2. Previous correlations between $S_{u}-M$ (mackintosh probe)

\begin{tabular}{|c|c|c|c|c|}
\hline Researcher & Soil types & Location & Equations & Remarks \\
\hline \multirow[b]{2}{*}{$\begin{array}{c}\text { Hossain \& Ali } \\
{[2]}\end{array}$} & Soft Clay & Saudi Arabia & $\mathrm{S}_{\mathrm{u}}(\mathrm{kPa})=\mathrm{K} \cdot \mathrm{M}$ & $\mathrm{K}=1.59-2.04$ \\
\hline & Alluvium & $\begin{array}{l}\text { Khozestan } \\
\text { province, South } \\
\text { of Iran }\end{array}$ & $\mathrm{S}_{\mathrm{u}}=2.5 \mathrm{M}$ & $\begin{array}{l}\text { from vane shear, } \\
\text { UU and UCT }\end{array}$ \\
\hline \multirow{2}{*}{ Fakher et al. [3] } & $\begin{array}{l}\text { Alluvium and } \\
\text { soft clay }\end{array}$ & \multirow{2}{*}{$\begin{array}{l}\text { Saudi Arabia } \\
\text { and Iran }\end{array}$} & $\mathrm{S}_{\mathrm{u}}=0.90 \mathrm{M}^{0.96}$ & \multirow{2}{*}{$\begin{array}{l}\text { from } \mathrm{N} \text { and } \mathrm{M} \\
\text { correlation and } \\
\text { Equation } 1\end{array}$} \\
\hline & Very soft soil & & $\begin{array}{c}\mathrm{S}_{\mathrm{u}}=0.64 \mathrm{M}+ \\
15.35\end{array}$ & \\
\hline \multirow{2}{*}{$\begin{array}{c}\text { Fatnanta et al. } \\
{[6]}\end{array}$} & Soft soil & \multirow{2}{*}{ Indonesia } & $\begin{array}{c}\mathrm{S}_{\mathrm{u}}= \\
0.94 \mathrm{M}+10.88\end{array}$ & \multirow{2}{*}{$\begin{array}{c}\text { vane shear \& } \\
\text { Mackintosh probe }\end{array}$} \\
\hline & $\begin{array}{l}\text { Medium } \\
\text { Stiff soil }\end{array}$ & & $\begin{array}{c}\mathrm{S}_{\mathrm{u}}= \\
0.63 \mathrm{M}+19.75\end{array}$ & \\
\hline
\end{tabular}

$\mathrm{M}$ represents the number of blows for $100 \mathrm{~mm}$ penetration of Mackintosh Probe. The first correlation was proposed by Hossain \& Ali [2] in 1990 for soft clay in Sabkha, Saudi Arabia, using field vane shear and Mackintosh probe. Later, Fakher et al. [3] proposed two equations. The first equation was derived from the results of a vane shear test, unconsolidated undrained test (UU) and unconfined compression test (UCT) with a Mackintosh probe. The second equation is based on the correlation of standard penetration test $(\mathrm{N})$ and Mackintosh probe (M) by combining data from Sabtan \& Shehata [4]. They proposed a new relationship as follows: 


$$
\mathrm{N}=0.15 \mathrm{M}^{0.96}
$$

By adopting Terzaghi et al. [5] equation $\left(S_{u}=6 N\right)$, they proposed a correlation of $S_{u}$ and (M) as:

$$
\mathrm{S}_{\mathrm{u}}=0.90 \mathrm{M}^{0.96}
$$

In 2013, Fatnanta et al. [6] proposed a correlation based on field vane shear test and Mackintosh probe test performed at Pekan Baru, Indonesia. They categorized correlations for very soft soil, soft soil, and medium stiff soil. The correlation of very soft soil is questionable because the undrained shear strength of very soft soil is higher than that of soft soil. Furthermore, the proposed equations are not valid if $\mathrm{M}$ is equal to zero.

\section{Data collection}

To develop the correlation of $\mathrm{Su}$ and M, the JKR probe and the vane shear tests were performed at the Research Centre for Soft Soil (RECESS) in Universiti Tun Hussein Onn Malaysia (UTHM). There are six points for the JKR probe test with maximum depth of 6.9 $\mathrm{m}$, while 12 points of vane shear test have been performed in close proximity (less than 0.3 $\mathrm{m}$ ) to ensure a good correlation obtained as shown in Fig. 2. The number of blows and undrained shear strength for each $300 \mathrm{~mm}$ penetration were recorded for JKR probe test. Additionally, a vane shear test was performed at every $0.6 \mathrm{~m}$ depth. The vane shear test was pushed statically to the desired depth and torque was applied at a rate of $6^{\circ}$ per minute.

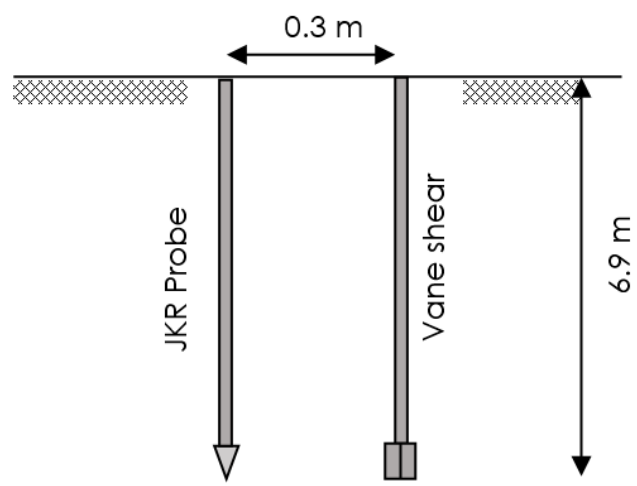

Fig. 2. Details of field testing

\section{Results and discussions}

\subsection{JKR probe test and vane shear test results}

The example results of the JKR probe test and vane shear test for point 1 and 2 are shown in Fig. 3 and 4. The results show a good pattern of number of blows and undrained shear strength. This increases with increasing soil depth due to increasing of stress in soil. From Fig. 3 and 4, it is clear that the hard layer exists from the ground surface to a depth of $1 \mathrm{~m}$. This result is due to present of fill material above the existing soft soil layer. These unsaturated fill soils are located above the ground water table, so their behaviors are 
influenced by the soil water characteristic curve (SWCC). The SWCC of residual soil or fill material in Malaysia has been discussed in detail by Mohd Fairus et al. [7].
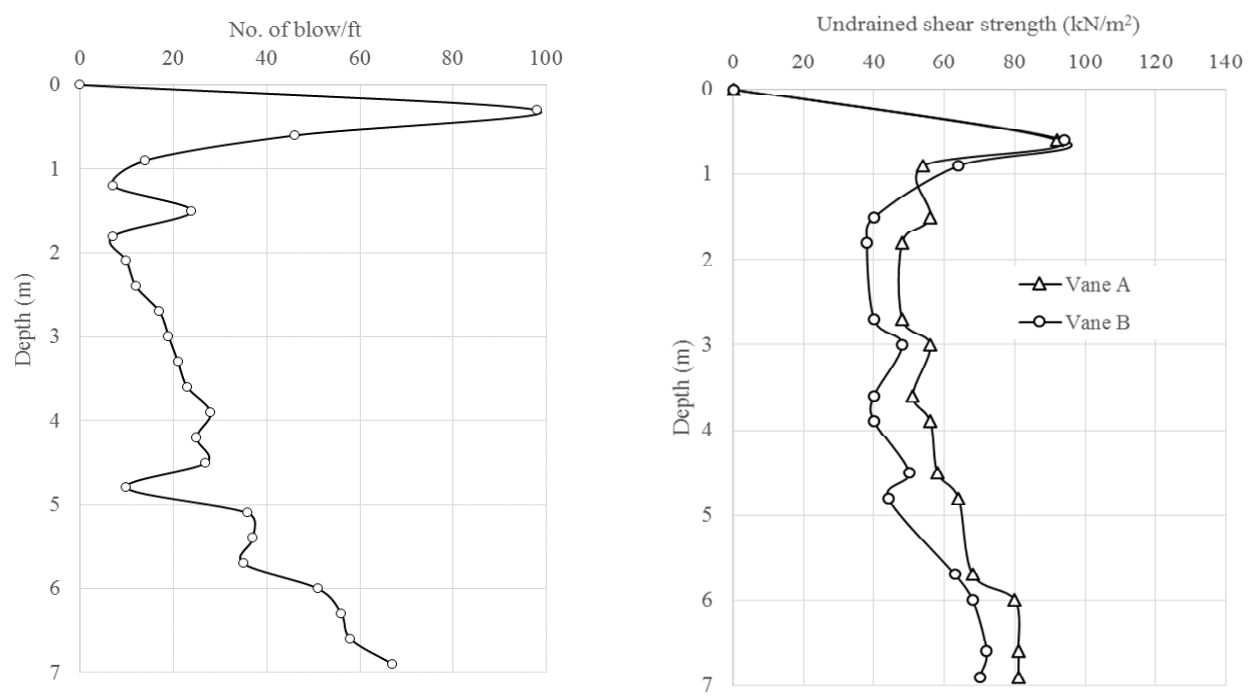

Fig. 3. Number of blow and undrained shear strength versus depth for point 1
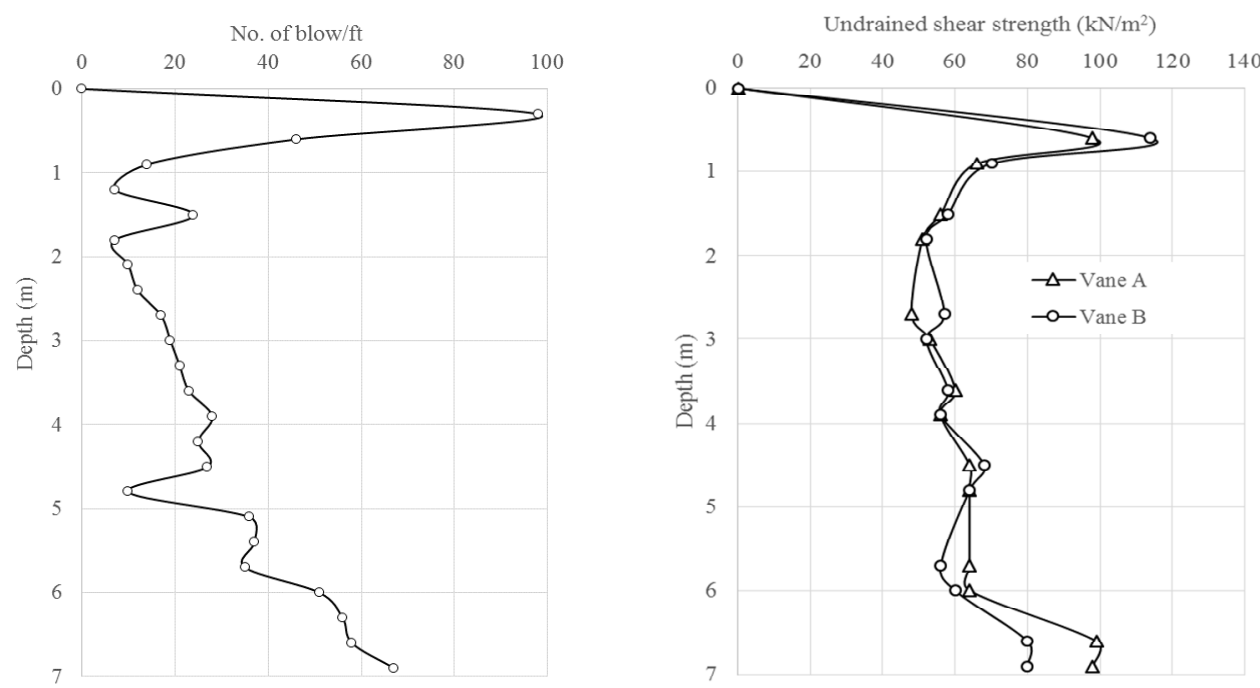

Fig. 4. Number of blow and undrained shear strength versus depth for point 2

\subsection{Proposed correlation of JKR probe $(J)$ and undrained shear strength $\left(\mathrm{S}_{\mathrm{u}}\right)$}

The number of data points obtained from the JKR probe test and the vane shear test were 138 and 168 respectively. The graph of undrained shear strength, $\mathrm{S}_{\mathrm{u}}$ versus the number of blows (J-Value) was constructed to develop the correlation.

A graph of undrained shear strength versus the number of blows is shown in Fig. 5. The power correlation was developed and the undrained shear strength could correlate with number of blows using the simplified equation as follows: 


$$
\mathrm{S}_{\mathrm{u}}=18 \mathrm{~J}^{0.3}
$$

where $S_{u}$ is the undrained shear strength $\left(\mathrm{kN} / \mathrm{m}^{2}\right)$ and $\mathrm{J}$ is the number of JKR probe blow. Referring to the coefficient of determination, $\mathrm{R}^{2}=0.5027$ for the proposed equation, it can be categorized as a moderately good correlation [8].

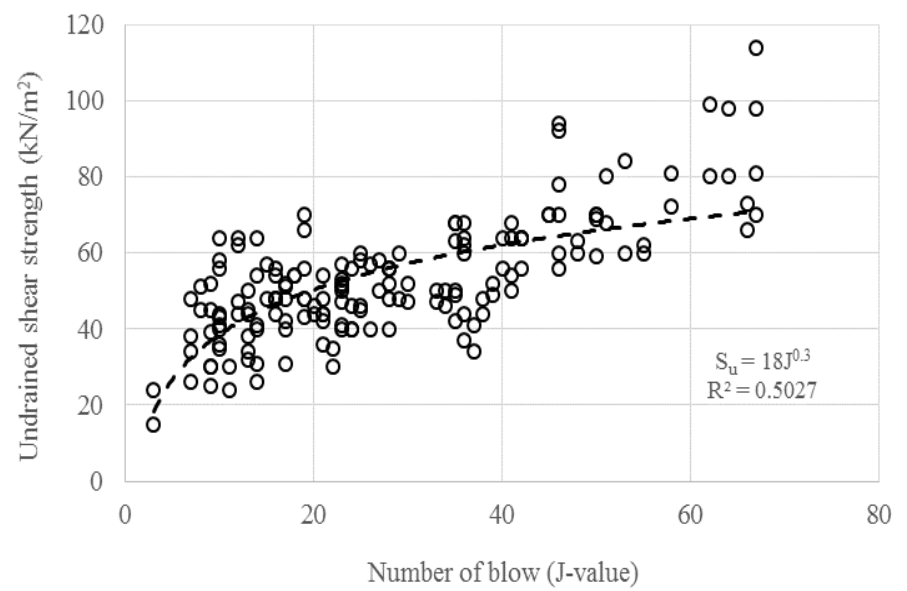

Fig. 5. Correlation of undrained shear strength and J-value

\subsection{Parametric studies of proposed correlation}

A parametric study was conducted to verify the proposed equation and make comparisons with past researchers. Fig. 6 contains a graph of undrained shear strength versus the number of blows from Mackintosh and JKR probe based on proposed equation. For practical applications, the results from Mackintosh and JKR probe are assumed to be identical.

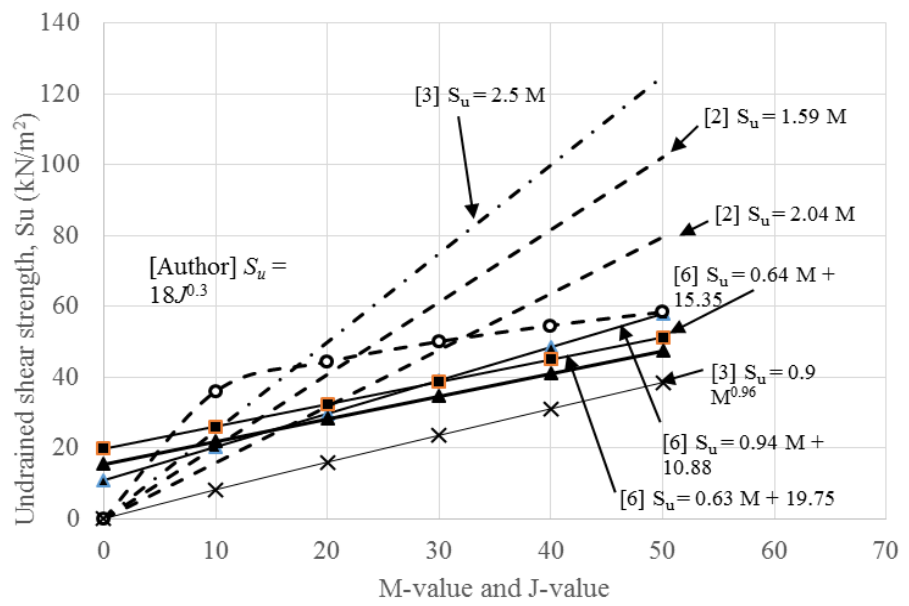

Fig. 6. Comparison of $\mathrm{S}_{\mathrm{u}}$ and $\mathrm{M}$ or $\mathrm{J}$ relationship from proposed equation

\section{Conclusion}


This study provides a correlation of JKR probe test and undrained shear strength of soft soil. From the study, the undrained shear strength can be predicted as $\mathrm{Su}=18 \mathrm{~J}^{0.3}$.

\section{References}

[1] S.S. Gue, Y.C. Tan, Subsurface investigation and interpretation of test results for foundation design in soft clay, Seminar on Ground Improvement-Soft Clay, UTM, Kuala Lumpur, 1-23 (2000)

[2] D. Hossain, K.M. Ai, Mackintosh-vs-vane estimation of undrained shear strength correlation for a Sabkha Clay of Saudi Arabia, Quarterly J. of Eng. Geology and Hydrogeology, 24, 269-272 (1990)

[3] A. Fakher, M. Khodaparast, C.J.F.P. Jones, The use of the mackintosh probe for site investigation in soft soils, Quarterly J. of Eng. Geology and Hydrogeology, 39, 189$196(2006)$

[4] A.A. Sabtan, W.M. Shehata, Mackintosh probe as an exploration tool, Bulletin of the International Association of Engineering Geology, Paris, 50, 89-94 (1994)

[5] K. Terzaghi, R.B. Peck, G. Desri, Soil Mechanics in Engineering Practice, 2nd ed., John Wiley and Sons, Chichester, (1967)

[6] F. Fatnanta, S.A. Nugroho and H. Rosyida, Determination of shear strength based on mackintosh probe test (in Indonesia language), Konferensi Nasional Teknik Sipil 7, Universitas Sebelas Maret, Surakarta, 175-182, (2013)

[7] M.F. Yusof, A.S. Setapa, S.A.A. Tajudin, A. Madun, M.H.Z. Abidin, A. Marto, The soil water characteristic curve of unsaturated tropical residual soil, IOP Conferences Series: Material Science and Engineering, 136, (2016)

[8] A. Marto, Volumetric compression of a silt under periodic loading, $\mathrm{PhD}$ Thesis, University of Bradford, England (1996) 